\title{
Masyarakat dan Kebudayaan Sekolah
}

\section{Oleh: Normina}

Humans are born already has a herd instinct to live, so be called a social animal. As a social animal instinct that bumans bave called gregariousness, the relationship between man and his fellow. Culture affects individuals in different ways but the individual also affects the culture resulting in social change. From birth to death man lives as members of society. Culture school education system to develop certain patterns of behavior in accordance with what is expected by the public and students. Life in the schools as well as the norms prevailing in situ can be called Culture School.

In the school there are some elements of culture are broadly as follows: Location of environment and physical infrastructure of schools, school curriculum, Persons values norms, regulatory systems, and climate school life. Meanwhile, according to Hedley Beare First, elements that are not visible matadan second element is visible

Keywords: Society, Culture and Schools

\section{A. Pendahuluan}

Manusia dilahirkan sudah mempunyai naluri untuk hidup berkawan, sehingga dia disebut sosial animal.Sebagai sosial animal manusia mempunyai naluri yang disebut gregariousness, pada hubungan antara manusia dengan sesamanya. Sehingga manusia hidup sebagai anggota masyarakat berarti adanya interaksi sosial dengan orang-orang di sekitar. Dengan demikian mengaruh dan mempengaruhi orang lain. Interaksi sosial sangat utama dalam tiap masyarakat.

Manusia adalah makhluk sosial, ia hidup dalam hubungannya dengan orang lain dan hidupnya bergantung pada orang lain. Karena itu manusia tak mungkin hidup layak di luar masyarakat. Masyarakat sangat luas dan dapat meliputi seluruh umat manusia. Masyarakat terdiri atas berbagai kelompok, yang besar maupun kecil bergantung pada jumlah anggotanya. Dua orang atau lebih dapat merupakan kelompok. Tiap orang menjadi anggota keluarga yang terdiri atas ibu-ayah, dan anak, atau keluarga besar yang juga memcakup paman, kakek, cucu, dan sebagainya.

Tiap anak di atas usia 6 tahun termasuk kelompok murid, mungkin juga menjadi anggota pramuka, perkumpulan oleh raga, band musik dan sebagainya. Dalam pengelompokan sering dibedakan kelompok primer dan kelompok sekunder. Kelompok primer adalah kelompok pertama dimana ia mula-mula berintegrasi dengan orang lain, yakni keluarga, kelompok sepermainan, dan lingkungan tetangga. Dalam kelompok primer terdapat hubungan temu-muka langsung dalam suasana akrab. Kelompok ini biasanya mempelajari kebiasaan yang fundamental seperti bahasa, soal baik buruh, kemampuan untuk mengurus diri sendiri, kerjasama dan bersaing, disiplin dan sebagainya. Kelompok primer ini disebut juga Gemeinschaft. Sedangkan kelompok sekunder dibentuk dengan sengaja atas pertimbangan tertentu bersadarkan kebutuhan tertentu seperti perkumpulan profesi, organisasi agama, partai politik. Anggotanya mungkin tak pernah saling bertemu. Kelompok sekunder ini dapat hidup lama melampaui suatu generasi. Kelompok sekunder ini sering disebut Gesellschaft. (S. Nasution, 2011; 60-61).

Manusia pada dasarnya adalah individu yang mempunyai kecenderungan untuk bermasyarakat. Memang manusia 
menurut para sosiolog adalah makhluk sosial. Kehidupan manusia akan bermakna bila dia hidup ditengah-tengah masyarakat lainnya. Oleh karena itu, Iman Qastalani mengatakan bahwa salah satu cabang dari iman seseorang adalah kemampuann yang bermasyarakat. Sehingga Allah Swt memberikan kehidupan yang baik dan kemurahan rezeki bagi orang yang selalu mengadakan kontak sosial dalam masyarakat.

Masalah kebudayaan juga diperhatikan dalam sosiologi, karena kebudayaan dan masyarakat manusia sebagai makhluk sosial merupakan dwitunggal yang tidak terpisahkan. Oleh karena itu, masyarakat adalah orang yang hidup bersama yang menghasilkan kebudayaan. Dengan demikian, tak ada masyarakat yang tidak mempunyai kebudayaan dan sebaliknya tak ada kebudayaan tanpa masyarakat sebagai wadah dan pendukunyanya.

Kebudayaan dapat dipandang sebagai cara-cara mengatasi masalahmasalah yang dihadapi. Ada masalah yang universal seperti memenuhi kebutuhan biologis. Nanum tiap masyarakat memilih cara yang dianggap paling sesuai sehingga tidak ada dua masyarakat yang sama kebudayaannya. Kebudayaan dipengaruhi oleh lingkungan fisik seperti iklim, topografi, kekeyaan alam dan sebagainya. Kebudayaan daerah tropis, berbeda dengan kebudayaan di daerah dingin, kebudayaan di daerah gurun berbeda kebudayaan yang berhutan. Namun menusia tidak semata-mata pasif, adanya barang tambang tidak dengan sendirinya menimbulkan industri. Untuk itu diperlukan inisiatif individu.
Walaupun kebudayaan sekolah merupakan bagian dari kebudayaan masyarakat luas. Namun mempunyai ciriciri yang khas sebagai suatu subculture. Sekolah bertugas untuk menyampaikan kebudayaan kepada generasi baru dan harus selalu memperhatikan masyarakat dan kebudayaan umum. Akan tetapi disekolah itu sendiri timbul pola-pola kelakuan tertentu. Ini mungkin sekolah mempunyai kedudukan yang agak terpisah dari arus umum kebudayaan.

\section{B. Pembahasan}

Sebagaimana halnya dengan keluarga dan institusi social lainya sekolah merupakan salah satu institusi sosial yang mempengaruhi proses sosialisasi dan berfungsi mewariskan kebudayaan masyarakat kepada anak. Sekolah merupakan suatu system sosial yang mempunyai organisasi yang unik dan pola relasi diantara para anggotanya yang bersifat unik, hal ini dikarenakan tiap-tiap sekolah memiliki aturan tata tertib,kebiasaan, upacara-upacara, mars/hymne sekolah, pakaian seragam dan lambang-lambang yang lain yang memberikan corak khas kepada sekolah yang bersangkutan.

\section{Pengertian Masyarakat dan Kebudayaan Sekolah}

Masyarakat (sebagai terjemahan istilah society) adalah sekelompok orang yang membentuk sebuah system semi tertutup (semi terbuku), dimana sebagian besar interaksi adalah antara individuindividu yang berbeda dalam kelompok tersebut. Kata "masyarakat sendiri berakar dari kata dalam bahasa Arab, Musyarak. Lebih abastraknya, sebuah masyarakat adalah suatu jaringan hubungan-hubungan antar entitas-entitas. 
Masyarakat adalah sebuah komunitas yang interdependen (saling tergantung satu sama lain). Umumnya, istilah masyarakat digunakan untuk mengacu sekelompok orang yang hidup bersama dalam satu komunitas yang teratur. (Radiansyah, 2008; 214).

Menurut Syaikh Taqyuddin AnNabhani, sekolompok manusia dapat dikatakan sebagai sebuah masyarakat apabila memiliki pemikiran, perasaan, serta system/aturan yang sama. Dengan kesemaan-kesamaan tersebut, manusia kemudian berinteraksi sesame mereka berdasarkan kemaslahatan. Masyarakat sering diorganisasikan berdasarkan cara utamanya dalam bermata pencaharian. Pakar ilmu sosial mengidentifikasikan adanya masyarakat pemburu, masyarakat bercocok taman, dan masyarakat agricultural intensif yang juga disebut masyaraakat peradaban. Sebagian pakar menganggap masyarakat industry dan pasca industry sebagai kelompok masyarakat yang terpisahkan dari masyarakat tradisional (Soerjono Soekanto, 2001;29).

Berikut di bawah ini adalah beberapa pengertian masyarakat menurut beberapa ahli sosiologi dunia, diantaranya:

a. Mac Iver dan Page yang mengatakan bahwa; Masyarakat ialah suatu sistem dari kebiasaan dan tata cara, dari wewenang dan kerja sama antara berbagai kelompok dan penggolongan, dari pengawasan tingkah laku serta kebebesankebebesan manusia. Keseluruhan yang selalu berubah ini kita namakan masyarakat. Masyarakat merupakan jalinan hubungan sosial dan masyarakat selalu berubah.

b. Ralph Linton, menyatakan masyarakat merupakan setiap manusia yang telah hidup dan bekerja bersama cukup lama sehingga mereka dapat mengatur diri mereka dan menganggap diri mereka sebagai suatu kesatuan sosial dengan batas-batas yang dirumuskan dengan jelas.

c. Karl Marx, masyarakat adalah suatu struktur yang menderita suatu ketegangan organisasi atau perkembangan akibat adanya pertentangan antara kelompokkelompok yang terbagi secara ekonomi.

d. Emile Durkheim, masyarakat merupakan suatu kenyataan hidup objektif pribadi-pribadi yang merupakan anggotanya.

e. Paul B.Horton \& C.Hunt, masyarakat merupakan kumpulan manusia yang relative mendiri, hidup bersama-sama dalam waktu yang cukup lama, tinggal diwilayah tertentu, mempenyai kebudayaan sama serta melakukan sebagian besar kegiatan di dalam kelompok/ kumpulan manusia tersebut

f. Selo Sumardjan, masyarakat adalab orang -orang yang hidup bersama dan menghasilkan kebudayaan. (Radiansyah, 2008; 216).

Dari lahir sampai mati manusia hidup sebagai anggota masyarakat. Hidup dalam masyarakat berarti adanya interaksi sosial dengan orang-orang disekitar dan dengan denikian mengalami pengaruh dan mempengaruhi orang lain. Masyarakat sangat luas dan dapat meliputi seluruh umat manusia. Masyarakat terdiri 
atas berbagai kelompok, yang besar maupun yang kecil bergantung pada jumlah anggotannya. Dua orang atau lebih dapat merupakan kelompok. Tiap orang menjadi anggota keluarga yang terdiri atas ibu-ayah dan anak, keluarga besar yang juga mencakup paman, kakek, cucu dan sebagainya. (Nurani Soyomukti, 2010; 408).

Dalam pengelompokan sering dibedakan kelompok primer dan kelompok sekunder. Kelompok primer adalah kelompok pertama dimana ia mula-mula berintegrasi dengan orang lain, yakni keluarga, kelompok sepermainan, dan lingkungan tetangga. Dalam kelompok primer terdapat hubungan temu-muka langsung dalam suasana akrab. Kelompok ini biasanya mempelajari kebiasaan yang fundamental seperti bahasa, soal baik buruh, kemampuan untuk mengurus diri sendiri, kerjasama dan bersaing, disiplin dan sebagainya. Kelompok primer ini disebut juga Gemeinschaft. Sedangkan kelompok sekunder dibentuk dengan sengaja atas pertimbangan tertentu bersadarkan kebutuhan tertentu seperti perkumpulan profesi, organisasi agama, partai politik. Anggotanya mungkin tak pernah saling bertemu. Kelompok sekunder ini dapat hidup lama melampaui suatu generasi. Kelompok sekunder ini sering disebut Gesellschaft. (S. Nasution, 2011; 60-61).

Manusia senantiasa mempunyai naluri yang kuat untuk hidup bersama. Bercampur untuk waktu yang cukup lama. Mereka sadar bahwa mereka merupakan satu kesatuan, dan mereka merupakan suatu system hidup bersama. System kehidupan bersama menimbulkan kebudayaan oleh karena itu, setiap anggota kelompok merasa terikat satu dengan lainnya. Apabila dibandingkan dengan makhluk hidup lain seperti hewan, misalnyan manusia tidak akan mengkin hidup sendiri. Manusia tanpa manusia lainnya pasti kan mati, manusia yang dikurung sendirinan di $\mathrm{d} \backslash$ suatu ruangan tertutup, pasti akan mengalami gangguan pada perkembangan pribadinya, sehingga lama kelamaan dia akan mati.

Oleh karena itu, manusia pada dasarnya mempunyai hasrat/keinginan yang kuat dalam dirinya untuk menjadi satu dengan sesamanya atau manusia lain di sekitarnya masyarakat. Dan keinginan untuk menjadi satu dengan lingkungan alam sekitarnya. Untuk dapat menghadapi dan menyesuaikan diri dengan keingginan lingkungan tersebut, yakni lingkungan sosial dan lingkungan alam, manusia mempergunakan fikiran, perasaan dan kehandak. Selain itu , maka dalam menyerasikan diri dengan lingkunganlingkungan tersebut manusia senantiasa hidup dengan sesaamanya, untuk menyempurnakan dan memperluas sikap tindakan agar tercapai kedamaian dengan lingkungannya.

Dengan demikian, maka suatu masyarakat sebenarnya merupakan system adaptif, oleh karena masyarakat wadah untuk memenuhi berbagai kepentingan dan tentunya juga untuk dapat bertahan. Namun disemping itu, masyarakat sendiri juga mempunyai berbagai kebutuhan yang harus dipenuhi, agar masyarakat itu dapat hidup terusmenerus. Kebutuhan-kebutuhan itu adalah diantaranya: a). adanya populasi, b). informasi. c). Energi. d). Materi. e). Sistem komunikasi. f). Sistem Produksi. g). Sistem distribusi. h).sistem organisasi 
sosial. i).sistem pengendelian sosial dan perlindungan warga masyarakat terhadap ancaman-ancaman yang tertuju pada jiwa dan harta bendanya.

Dalam hal ini masyarakat mempunyai komponen- komponen dasar yaitu:

a. Populasi, adalah warga- warga suatu masyarakat yang dilihat dari sudut pandangan kolektif. Secara sosiologis, maka aspek-aspek sosiologis yang perlu dipertimbangkan adalah; aspekaspek genetik yang konstan, veriabelvariebel genetik dan veriabel-veriabel demografis.

b. Kebudayaan, adalah hasil karya, cipta dan rasa dari kehidupan bersama yang mencukup, sistem lambang-lambang dan informasi.

c. Hasil-hasil kebudayaan material.

d. Organisasi sosial, ialah jaringan hubungan antara warga-warga masyarakat yang bersangkutan, yang antara lain mencakup; a). warga masyarakat secara individual. b). Peranan-peranan. c). Kelompok kelompok sosial, d). Kelas -kelas sosial.

e. Lembang-lembang sosial dan sistemnya.

Dengan demikian dapatlah dikatakan bahwa masyarakat senantiasa merupakan suatu system, yang mencakup berbagai komponen dasar yang saling berkaitan secara fungsional.(Soerjono Soekanto, 2001; 26-29).

Sedangkan kebudayaan sekolah Sistem pendidikan mengembangkan pola kelakuan tertentu sesuai dengan apa yang diharapkan oleh masyarakat dan muridmurid. Kehidupan di sekolah serta norma-norma yang berlaku di situ dapat disebut dengan Kebudayaan Sekolah.

Budaya sekolah merupakan kebiasaan-kebiasaan, nilai-nilai, norma, ritual, mitos yang dibentuk dalam perjalanan panjang sekolah yang dipegang bersama oleh kepala sekolah, guru, staf administrasi, dan siswa sebagai dasar mereka dalam memahami dan memecahkan berbagai persoalan yang muncul di sekolah (Zamroni, 2003; 149.)

Walaupun kebudayaan sekolah merupakan bagian dari kebudayaan masyarakat luas. Namun mempunyai ciriciri yang khas sebagai suatu "subculture". Sekolah bertugas untuk menyampaikan kebudayaan kepada generasi baru dan harus selalu memperhatikan masyarakat dan kebudayaan umum. Akan tetapi disekolah itu sendiri timbul pola-pola kelakuan tertentu. Ini mungkin sekolah mempunyai kedudukan yang agak terpisah dari arus umum kebudayaan.

Sebagaimana halnya dengan keluarga dan institusi social lainya sekolah merupakan salah satu institusi sosial yang mempengaruhi proses sosialisasi dan berfungsi mewariskan kebudayaan masyarakat kepada anak. Sekolah merupakan suatu system sosial yang mempunyai organisasi yang unik dan pola relasi diantara para anggotanya yang bersifat unik, hal ini dikarenakan tiap-tiap sekolah memiliki aturan tata tertib, kebiasaan, upacara-upacara, mars/hymne sekolah, pakaian seragam dan lambanglambang yang lain yang memberikan corak khas kepada sekolah yang bersangkutan.

Timbulnya sub-Kebudayaan sekolah juga terjadi oleh sebab sebagian yang cukup besar dari waktu murid 
terpisah dari kehidupan orang dewasa. Dalam situasi serupa ini dapat berkembang pola kelakuan yang khas bagi anak muda yang tampak dari pakaian, bahasa, kebiasaan kegiatan-kegiatan serta upacara-upacara. sebab lain timbulnya kebudayaan sekolah ialah tugas sekolah yang khas yakni mendidik anak dengan menyampaikan sejumlah pengetahuan, sikap, terampilan yang sesuai dengan kurikulum dengan metode dan teknik control tertentu yang berlaku disekolah itu.

\section{Dalam melaksanakan kurikulum} dan ekstra-kurikulum berkembang sejumlah pola kelakuan yang khas bagi sekolah, yang berbeda dengan yang terdapat pada kelompok -kelompok lain dalam masyarakat. Tiap kebudayaan mengandung bentuk kelakuan yang diharapkan dari anggotanya. Di sekolah diharapkan bentuk kelakuan tertentu dari semua murid dan guru. Itulah yang menjadi norma bagi setiap murid dan guru. Norma ini nyata dalam kelakuan anak dan guru, dalam peraturan-peraturan sekolah, dalam tindakan dan hukum terhadap pelanggaran, juga dalam berbagai kegiatan seperti upacara-upacara. (S. Nasution, 2011; 64-64).

a. Kenaikan kelas

Belajar dengan rajin agar naik kelas merupakan patokan yang mempengaruhi kehidupan anak selama bersekolah. Untuk itu ia harus menguasai bahan pelajaran yang ditentukan oleh kurikulum yang sering diolah dalam bentuk buku pelajaran, diktat atau kitab catatan. Dengan nilai atau tes ulangan guru menilai kemampuan anak. Hak guru memberi angka memberinya kekuasaan yang disegani murid. Ada juga guru yang bila perlu menggunakan angka itu untuk menegakkan kekuasaannya. Guru itu disebut "killer" sangat ditakuti.

Angka rapor menjadi dasar bagi kenaikan kelas. Pemberian rapor dan penentuan kenaikan kelas sering dilakukan dengan upacara tertentu sekalipun sederhana. Tinggal kelas merupakan masalah yang berat bagi murid. Bagi anak yang bersangkutan ini bahwa ia akan ditinggalkan oleh temantemannya selama setidaknya satu tahun dan ia harus masuk kelompok anak-anak yang lebih muda daripadanya yang selama ini lebih rendah kedudukannya. Oleh sebab itu kenaikan kelas merupakan hal yang sangat penting maka murid-murid biasanya belajar untuk memperoleh angka yang baik, walaupun ilmu itu juga penting.

b. Upacara-upacara

Peristiwa yang biasanya dilakukan dengan upacara ialah penerimaan murid baru. Pada waktu yang lalu murid-murid SMA turut melakukan masa perkenalan, meniru kakak-kakaknya diperguruan tinggi. Sebenarnya mereka mengikuti jejak mahasiswa zaman kolonial, yang menerima mahasiswa baru dengan upacara perpeloncoan. Masa "perkenalan" itu memang banyak dan sering menyimpang dari tujuannya yakni memperkenalkan sekolah sebagai lembaga pendidikan kepada siswa-siswa baru.

Upacara yang menggembirakan ialah upacara wisuda yang melepaskan para siswa yang telah lulus yang kemudian akan melanjutkan pelajaran pada lembaga pendidikan yang lebih tinggi atau mengadu nasibnya dalam dunia pekerjaan. 
Upacara itu melambangkan beberapa hal:

- Untuk menyatakan besarnya nilai pendidikan bagi pembinaan generasi muda dan kepercayaan bahwa pendidikan membawa kemajuan bagi setiap siswa. Dalam penyelenggaraan sekolah sering diperlukan dukungan dan bantuan orang tua, spiritual, maupun materiil sebagai partner pemerintah.

- Bagi mereka yang lulus, wisuda itu merupakan pengakuan atas taraf pendidikan yang telah mereka capai. Wisuda mengakhiri periode tertentu dalam hidupnya dan membuka lembaran baru serta memasukiperiode yang baru dan masa menuju kedewasaan. Selain itu wisuda merupakan tanda penghargaan atas keberhasilan siswa dalam pelajarannya yang diperoleh dengan jerih payah.

c. Upacara Bendera

Ada sekolah yang memulai sekolah dengan mengumpulkan muridmurid untuk upacara namun ada juga sekolah swasta mungkin mulai dengan do'a serta pengumuman dan petunjuk dari kepala sekolah. Ada pula yang memulai dengan senam pagi atau dengan kegiatan lain.

Upacara ini selain mempunyai fungsi control juga menanamkan rasa identifikasi anak dengan sekolahnya dan semangat persatuan serta rasa turut bertanggung jawab atas nama baik sekolahnya.

Suatu upacara yang diwajibkan bagi tiap sekolah dinegara kita adalah upacara bendera pada setiap hari senin tiap minggu dan pada tanggal 17 tiap bulan. Upacara bertujuan untuk menanamkan rasa kebangsaan dengan meresapkan dasar pikiran, dan cita-cita serta norma-norma yang terkandung dalam Undang-Undang Dasar 1945, Pancasila, dan Sumpah Pemuda. Kesempatan ini juga dapat digunakan oleh Kepala Sekolah untuk berbagai pengumuman dan petunjuk-petunjuk lainnya demi kebaikan sekolah. Upacara dianggap sebagai kesempatan yang yang penting untuk menyampaikan dan menerima pesan-pesan.

Upacara-upacara lain yang terdapat disekolah ialah pergantian pengurus OSIS, penyerahan tanda penghargaan atas kemenangan atas kemenangan dalam berbagai pertandingan dan perlombaan kemenangan ini sangat meningkatkan rasa kebangsaaan atas sekolah sendiri serta identifikasi murid dengan sekolahnya.

\section{Unsur Budaya Sekolah}

Bentuk budaya muncul sebagai suatu fenomena yang unik dan menarik, karena pandangan sikap, perilaku yang hidup dan berkembang dalam sekolah pada dasarnya mencerminkan kepercayaan dan keyakinan yang mendalam dan khas dari warga sekolah. Kebudayaan sekolah itu memiliki beberapa unsur-unsur penting yaitu; (S. Nasution, 2011; 64-64)

a. Letak lingkungan dan prasarana fisik sekolah (gedung sekolah dan perlengkapan lainnya).

b. Kurikulum sekolah yang memuat gagasan-gagasan maupun fakta-fakta yang menjadi keseluruhan program sekolah

c. Pribadi-pribadi yang merupakan warga sekolah yang terdiri atas guruguru, siswa, tenaga administrasi, tata usaha, dan non teaching specialist. 
d. Nilai-nilai norma, sistem peraturan, dan iklim kehidupan sekolah

e. Hedley Beare mendeskripsikan unsurunsur budaya sekolah dalam dua kategori:

(bttp/blog

umy,acid/wiwinsundari, 2011).

1) Unsur yang tidak kasat mata

Unsur yang tidak kasat mata adalah filsafat atau pandangan dasar sekolah mengenai kenyataan yang luas, makna hidup atau yang di anggap penting dan harus diperjuangkan oleh sekolah. Dan itu harus dinyatakan secara konseptual dalam rumusan visi, misi, tujuan dan sasaran yang lebih kongkrit yang akan di capai oleh sekolah. (S. Nasution, 2011; 64-64).

2). Unsur yang kasat mata dapat termenifestasi secara konseptual meliputi : a.) visi,misi, tujuan dan sasaran, b).kurikulum, c). bahasa komunikasi, d). narasi sekolah, dan narasi tokohtokoh, e). struktur organisasi f.) ritual, dan upacara, g.) prosedur belajar mengajar, h.) peraturan sistem ganjaran/ hukuman, i). layanan psikologi sosial, j.) pola interaksi sekolah dengan orang tua, masyarakat dan yang meterial dapat berupa : fasilitas dan peralatan, artifiak dan tanda kenangan serta pakaian seragam.

3). Unsur-unsur budaya sekolah jika ditinjau dari usaha peningkatan kualitas pendidikan sebagai berikut : (Djemari Mardapi,2011;28)

\section{a. Kultur Sekolah yang Positif}

Kultur sekolah yang positif adalah kegiatan-kegiatan yang mendukung peningkatan kualitas pendidikan, misalnya kerjasama dalam mencapai prestasi, penghargaan terhadap prestasi, dan komitmen terhadap belajar.

b. Kultur Sekolah yang Negative

Kultur sekolah yang negatif adalah kultur yang kontra terhadap peningkatan mutu pendidikan. Artinya resisten terhadap perubahan, misalnya dapat berupa: siswa takut salah, siswa takut bertanya, dan siswa jarang melakukan kerja sama dalam memecahkan masalah.

\section{c. Kultur Sekolah yang Netral}

Yaitu kultur yang tidak berfokus pada satu sisi namun dapat memberikan konstribusi positif tehadap perkembangan peningkatan mutu pendidikan. Hal ini bisa berupa arisan keluarga sekolah, seragam guru, seragam siswa dan lain-lain.

\section{Hubungan Kebudayaan Sekolah dengan Masyarakat}

Dalam terminologi kebudayaan, pendidikan yang berwujud dalam bentuk lembaga atau instansi sekolah dapat dianggap sebagai pranata sosial yang di dalamnya berlangsung kegiatan tertentu yaitu interaksi antara pendidik dan peserta didik sehingga mewujudkan suatu sistem nilai atau keyakinan, norma juga kebiasaan yang di pegang bersama.

Pendidikan sendiri adalah suatu proses budaya. Namun nilai-nilai yang mana yang seharusnya dikembangkan atau dibudayakan dalam proses pendidikan yang berkualitas. Dengan demikian sekolah menjadi tempat dalam mensosialisasikan nilai-nilai budaya yang tidak hanya terbatas pada nilai-nilai keilmuan saja, melainkan semua nilai-nilai kehidupan yang memungkinkan mampu mewujudkan manusia yang berbudaya. Dalam hal ini karakteristik peran kultur 
sekolah berdasarkan sifatnya dapat dibedakan menjadi tiga yakni:

\section{a. Bernilai Strategis}

Adalah kultur yang dapat berimbas dalam kehidupan sekolah secara dinamis. Misalnya memberi peluang pada warga sekolah untuk bekerja secara efisien, disiplin dan tertib. Kultur sekolah merupakan milik kolektif bukan milik perorangan, sehingga budaya sekolah dapat dikembangkan dan dilakukan oleh semua warga sekolah.

\section{b. Memiliki Daya Ungkit}

Kultur yang memliki daya gerak akan mendorong semua warga sekolah untuk berprestasi, sehingga kerja guru dan semangat belajar siswa akan tumbuh bilamana dipacu dan di dorong, dengan dukungan budaya yang memiliki daya ungkit yang tinggi. Misalnya kinerja sekolah dapat meningkat jika disertai dengan imbalan yang pantas, penghargaan yang cukup, dan proporsi tugas yang seimbang. Begitu juga dengan siswa akan meningkat semangat belajranya, bila mereka diberi penghargaan yang memadai, pelayanan yang prima, serta didukung dengan sarana yang memadai.

\section{c. Berpeluang Sukses}

Budaya yang berpeluang sukses adalah budaya yang memiliki daya gerak yang tinggi. Hal ini sangat penting untuk menumbuhkan rasa keberhasilan dan rasa mampu untuk melaksanakan tugas dengan baik. Misalnya budaya gemar membaca. Budaya membaca di kalangan siswa akan dapat mendorong mereka untuk banyak tahui tentang berbagai macam persoalan yang mereka pelajari di lingkungan sekolah. Demikian juga bagi guru mereka semakin banyak pengetahuan yang diperolah, tingkat pemahaman semakin luas, semua ini dapat berlangsung jika disertai dengan kesadaran, bahwa mutu/ kualitas yang akan menentukan keberhasilan seseorang.

Dengan berpijak pada karakteristik diatas, maka di dapatkan peran kultur sekolah adalah untuk memperbaiki kinerja sekolah, membangun komitmen warga sekolah, serta membuat suasana kekeluargaan, kolaborasi, ketahanan belajar, semangat terus maju, dorongan bekerja keras dan tidak mudah mengeluh dan suasana batin yang menyenangkan di antara warga sekolah.

\section{Pengaruh Kebudayaan Sekolah Terhadap Masyarakat}

Sekolah yang berorentasi penuh kepada kehidupan masyarakat disebut Community school atau sekolah masyarakat.Sekolah ini berorentasi pada masalah-masalah kehidupan dalam masyarakat seperti masalah usaha manusia melestarikan alam, memanfaatkan sumber-suber alam dan manusia, masalah kesehatan, kewarganegaraan, penggunaan waktu senggang, komunikasi, transport, dan sebagainya.Dalam kurikulum ini anak dididik agar turut serta dalam kegiatan masyarakat. Pelajaran mengutamakan kerja kelompok. Dengan sendirinya kurikulum itu fleksibel, berbeda dari sekolah ke sekolah,dari tahun ke tahun dan tidak dapat ditentukan secara uniform.murid-murid 
mempelajari lingkungan sosialnya untuk mengidentifikasi masalah-maslah yang dapat dijadikan pokok bagi suatu unit pelajaran.Khususnya yang memberi kesempatan kepada murid-murid untuk meningkatkan mutu kehidupan dalam masyarakat sekitarnya.

Dalam melaksanakan program sekolah, masyarakat turut sertakan. Tokoh-tokoh dari setiap aspek kehidupan masyarakat seperti dari dunia perusahaan, pemerintah, agama, politik, dan sebagainya.diminta bekerja sama dengan sekolah dalam peroyek perbaikan masyarakat. Untuk itu diperlukan masyarakat yang turut bertanggung jawab atas kesejahteraan masyarakat dan pendidikan anak.Sekolah dan masyarakat dalam hal ini bekerja sama dalam suatu aksi social.

Banyak kesulitan yang dihadapi bila kita ingin menjalankan sekolah seperti itu.Meminta waktu dan tenaga tokoh-tokoh masyarakat dalam suatu proyekpelajaran sekolah akan bayank menemui rintangan. Demikian pula bila anak ingin mengunjungi berbagai kantor, Pabrik, Perusahaandan sebagainya.Kurikulum sekolah sepenuh nya di dasarkanatas maslah-maslah masyarakat yang mendapat kencamanyang pedasdari golongan yang menginginkan kurikulum akademis berdasarkan disiplin ilmu.Setelah peluncuran sputnik kurikulum yang subject-contered berupa mata pelajaranatau bidang setudi kembali mendapat peranan utama.

Sekarang mungkin jarang terdapat orang yang berpegang sepenuhnya pada prinsip-prinsip community school.Akan tetapi walaupun kurikulum bersifat subject- centered, perlu juga berorientasi pada anak dan masyarakat. Tak mungkin kurikulum efektif tanpa memperhitungkan anak dan tak ada kurikulum yang tidak mempersiapkan anak untuk masyarakat.Setiap sekolah harus relevan dengan kebutuhan masyarakat karena sekolah didiirikan oleh masyarakat untuk mempersiapkan anak untuk masyarakat. Maka kerena itu guru perlu mempelajari dan mengenal masyarakat sekitarnya.

\section{Simpulan}

Manusia dilahirkan sudah mempunyai naluri untuk hidup berkawan, sehingga dia disebut sosial animal.Sebagai sosial animal manusia mempunyai naluri yang disebut gregariousness,pada hubungan antara manusia dengan sesamanya. Sehingga manusia hidup sebagai anggota masyarakat berarti adanya interaksi sosial dengan orangorang di sekitar. Dengan demikian mengaruh dan mempengaruhi orang lain. Interaksi sosial sangat utama dalam tiap masyarakat.

Kebudayaan mempengaruhi individu dengan berbagai cara akan tetapi individu juga mempengaruhi kebudayaan sehingga terjadi perubahan sosial. Dari lahir sampai mati manusia hidup sebagai anggota masyarakat. Hidup dalam masyrakat berarti adanya interaksi sosial dengan orang-orang di sekitar dan dengan demikian mengalami pengaruh dan mempengaruhi orang lain.Interaksi sosial sangat utama dalam tiap masyarakat. Hubungan antara individu itu bukan sepihak melainkan timbal balik. Kebudayaan mempengaruhi individu dengan berbagai cara akan tetapi individu juga mempengaruhi kebudayaan sehingga terjadi perubahan sosial. 


\begin{tabular}{ll} 
kebudayaan sekolah Sistem & fisik sekolah, Kurikulum sekolah, Pribadi- \\
pendidikan mengembangkan pola & pribadi Nilai-nilai norma , sistem \\
kelakuan tertentu sesuai dengan apa yang & peraturan, dan iklim kehidupan sekolah. \\
diharapkan oleh masyarakat dan murid- & Sedangkan menurut Hedley Beare 1. \\
murid. Kehidupan di sekolah serta & Unsur yang tidak kasat mata, 2. Unsur \\
norma-norma yang berlaku di situ dapat & yang kasat mata \\
disebut dengan Kebudayaan Sekolah. & \multicolumn{1}{c}{ Pendidikan adalah suatu proses } \\
Budaya sekolah merupakan kebiasaan- & budaya. Sekolah menjadi tempat dalam \\
kebiasaan, nilai-nilai, norma, ritual, mitos & mensosialisasikan nilai-nilai budaya yang \\
yang dibentuk dalam perjalanan panjang & tidak hanya terbatas pada nilai-nilai \\
sekolah yang dipegang bersama oleh & keilmuan saja, melainkan semua nilai-nilai \\
kepala sekolah, guru, staf administrasi, & kehidupan yang memungkinkan mampu \\
dan siswa sebagai dasar mereka dalam & mewujudkan manusia yang berbudaya. \\
memahami dan memecahkan berbagai & Dalam hal ini karakteristik peran kultur \\
persoalan yang muncul di sekolah & sekolah berdasarkan sifatnya dapat \\
Dalam kebudayaan sekolah ada & dibedakan menjadi tiga yakni: 1. Bernilai \\
beberapa unsur yang secara garis besar & Strategis, 2. Memiliki Daya Ungkit. 3. \\
yaitu: Letak lingkungan dan prasarana & Berpeluang Sukses
\end{tabular}

\section{DAFTAR PUSTAKA}

Abu Ahmadi, Sosiologi Pendidkan, Jakarta:PT. Rineka Cipta, Jakarta, 2004.

Djemari Mardapi, Pola Induk Sistem Pengujian Hasil KBM Berbasis Kemampuan Dasar SMU: Pedoman Umum, Jakarta: Dirjen Dikdasmen, Direktorat Dikmenum, 2003.

Prof. Dr. S. Nasution MA. Sosiologi Pendidikan. Bumi Aksara, Jakarta, 2011.

Zamroni, Paradigma Pendidikan Masa Depan, Yogyakarta: Bigraf Publishing, 2003.

http:/ / sartikabinata.wordpress.com/2011/11/18/masyarakat-dan-kebudayaan-sekolah/

http:/ / sartikabinata.wordpress.com/2011/11/18/masyarakat-dan-kebudayaan-sekolah/

bttp://blog.umy.ac.id/wiwinsundari/2011/11/09/budaya-sekolah-school-culture 